\title{
Prejudice of Mark in the Middle Classes: Text and Context of Oracy Nogueira's "Pretos and Mulatos" '
}

\author{
Maria Laura Viveiros de Castro Cavalcanti \\ Federal University of Rio de Janeiro
}

Pretos e Mulatos entre as Camadas Médias ["Pretos and Mulatos among the Middle Classes"] is an unpublished text written in 1985 by Oracy Nogueira (1917-1996). The original pages (preserved thanks to the Fundo Oracy Nogueira, ${ }^{2}$ today under the care of the Casa de Oswaldo Cruz in Rio de Janeiro) indicate that it was written with the intent of being published. The 104 typed pages (hand-numbered by the author, full of both typed and handwritten scribbles and corrections) are preceded by some "notes for publication" (on how to organize the table of contents, footnotes, reference bibliography, and headings/subheadings). It is not known where it was to be published and why it was not. This short

\footnotetext{
1 In Brazil the terms used for racial classification are part of a cultural domain loaded with symbolic meaning and are difficult to translate. As we did in the edition of Nogueira's previously unpublished research appearing in this same issue, we have opted to leave these terms in Portuguese (in italics), followed by our "best approximate translation in English" (in quotation marks). The problem immediately becomes evident in the translation of the terms preto (used in the title of Nogueira's article) and negro, also used on occasion by the author. Literal translations of preto and negro would be "black" and "negro." The cultural sense of Brazil's negro, however, differs from the U.S.'s "negro." Since the 1980 os in Brazil, the term negro tends to bestows an element of ethnic value, while "negro" in English is more neutral and it is the term "black" that bestows added ethnic value. In the United States, there is also the highly discriminatory and pejorative "nigger," practically banned from a white person's lexicon and restricted to use exclusively among blacks in the banter of intimate relationships. Preto, in turn, the most commonly used term in Nogueira's research on the traditional racial classification system in the 1940s and 1950 , is still in popular use today, although the term negro has become hegemonic in academic and politically correct circles. There is still the subtle nuance on the spectrum of color - preto retinto [dark black], mulato claro or escuro [light or dark mulato], pardo, moreno - characteristics of racial prejudice of mark, as identified by Nogueira. These terms, while they may not be common in academic literature, continue to be used widely in the country. Some of Nogueira's passages will need editorial notes on usage of terms and meaning in the context of how a term is used.
}

2 The Fundo Oracy Nogueira ["Oracy Nogueira Archive"] results from my research on the making of social sciences in Brazil from 1940-1960 conducted in the Institute of Philosophy and Social Sciences of the Federal University of Rio de Janeiro. The first steps of this research followed the valuable autobiographical elements presented by Nogueira in his "Introduction" to Tanto preto quanto branco (Nogueira, 1985). The Archive was established in 2007 with support from the Fundação de Amparo à Pesquisa no Estado do Rio de Janeiro (FAPERJ). I directed the Fundo until 2012, when I oversaw its donation from the family to the Casa de Oswaldo Cruz, Fundação Oswaldo Cruz, in Rio de Janeiro [http:/|arch.coc.fiocruz.br]. 
article commends the welcome opportunity for its publication in the present issue of the journal vibrant ${ }^{3}$ and seeks to place it historically and in the context of the author's body of work.

Although "Pretos and Mulatos" remained unpublished, Nogueira did publish a major work that same year of 1985: Tanto preto quanto branco [Both Black and White] (Nogueira 1985), a book that brough $t$ the author's notable contribution on Brazil's racial prejudice formulated in the $1950 \mathrm{~s}$ to a new moment of the country's history and social sciences. The transitional political process then underway in the country - from military dictatorship to democracy - was gaining enthusiastic momentum in 1984 with the Diretas Já ["Elections Now"] campaign. The social movements that arose in the late 1970s were flourishing, with wide debates about both politics as well as specific rights. In the mid-1980s, the women's, gay, and black movements were all thriving, especially the Movimento Negro Unificado ["Unified Black Movement] (MNU). Launched at a public protest in São Paulo on 7 July 1978 in response to discrimination against four black youths in the Tietê Regattas Club, the MNU movement reverberated and spread throughout Brazil. In addition to the struggle against the so-called "myth of racial democracy," the movement sought greater participation of blacks in higher education.

A catalyst for Oracy Nogueira's research was an article by movement leader Neusa Barbosa published in the Folha de São Paulo [a newspaper in São Paulo] on 6 November 1983. In it, Barbosa pointed out the miniscule number of blacks ( $1 \%)$ among the graduates from two major universities in São Paulo (Universidade de São Paulo - USP - and Pontifícia Universidade Católica) as well as their almost total absence among professors and mid- and high-level administrators. At the time, the MNU struggle helped motivate Oracy Nogueira to undertake the research for "Pretos and Mulatos among the Middle Classes." In addition, the 1980 census provided updated population data categorized by skin color and new academic research on race relations was being published.

3 I would like to thank the editors of this issue of Vibrant for the opportunity to publish Nogueira's original text as well as this brief article. Special acknowledgement and thanks to Yvonne Maggie for her support during preparation process. 
In the early 1980 s there was little discussion about racial quotas ${ }^{4}$ or how procedures for access higher levels in public universities should be changed. These discussions came years later, in the late 199os, and especially after the United Nations held the World Conference against Racism, Racial Discrimination, Xenophobia and Related Intolerance in Durban, South Africa in September 2001.

The sociopolitical context in Brazil was completely different, and "Pretos and Mulatos among the Middle Classes" - completed in 1985 - provides a valuable record of this historical moment. Even more, Nogueira's research gives us an enticing development of his fertile thinking on the dynamic of racial relations and racism in Brazil. For all these reasons, to read Nogueira's research now calls for contextualization, which we propose here. It is important that the reader become familiar with some generally little known aspects of Nogueira's professional work and career. It is also important to place "Pretos and Mulatos among the Middle Classes" in the context of what we now know about Nogueira's work. His book Tanto preto quanto branco, published in the same year of the writing of "Pretos and Mulatos" (1985), provides a keen perspective on the author's motivations.

Tanto preto quanto branco (Nogueira 1985) brings together two notable texts. The first - the culmination of a long journey of study, research and reflection - is the powerful Preconceito racial de marca e preconceito racial de origem ["Racial prejudice of mark and racial prejudice of origin"], originally presented in 1954 at the International Congress of Americanists in São Paulo. ${ }^{5}$ The second text, written 12 years earlier, marks the very beginnings of the author's comprehensive approach to Brazilian racial prejudice. It is the astute Atitude desfavorável de alguns anunciantes de São Paulo em relação aos empregados de cor ["Unfavourable attitudes by some advertisers in relation to employees of color in São Paulo"], originally published in

4 For discussion on establishment of racial quotas in public universities ([Racial Quotas Draft Bill] or PL 73/1999) and the so-called "Statute of Racial Equality" (PL 3.198/200o), see Fry, Maggie, Maio, Monteiro and Santos (orgs.) (2007). For a specific case study, see Maio and Santos (2005). For a broader critical perspective on the persistent application of the notion of race and its racist implications in the present, see Fry, 2005.

5 "Preconceito racial de marca e preconceito racial de origem" was also published in the classics section of the magazine Tempo Social (Vol. 19, No. 1. November 2006, pp. 287-308). Versions in English and Spanish (translated by Nogueira himself) were published in the online journal Vibrant (Virtual Brazilian Anthropology). Vol. 5, No. 1, Jan-Jun 2008 in the section Déjà Lu. 
1942 in the journal Sociologia based on a Master's course paper. The course teacher was Dr. Donald Pierson, who was also his thesis advisor. In the article, the young student formulated a hypothesis (later fully stated in the first text mentioned above) on the presence of a type of racial prejudice in Brazil unlike the racial prejudice found in countries such as the United States and South Africa and also not synonymous with class prejudice, as other Brazilians leftwing thinkers maintained.

Nogueira had planned to include a third text in the book: "Relações raciais no Município de Itapetininga, São Paulo" ["Race relations in the Municipality of Itapetininga, São Paulo"], an important account resulting from his participation from 1952 to 1954 in the UNESCO-sponsored race-relations research conducted in the states of Pernambuco, Bahia, Rio de Janeiro and São Paulo. Before then, Nogueira's work had only been published in a collection edited by Bastide and Fernandes (1955), a compilation of research studies conducted in São Paulo. ${ }^{6}$ As previously stated (Cavalcanti 1996), the Itapetininga study shares an organic relation with the 1942 article and the 1954 comparative essay and must be included in a balanced evaluation of Nogueira's work.

Nogueira's research on racial relations in Itapetininga (which he usually refers to as the "Report") examines the patterns in black/white relations in this municipality of the state of São Paulo over three centuries (mid-16oos to mid-19oos), weaving history and statistical data with ethnography and direct observation. In the best tradition of community studies, Itapetininga was the locus of a comprehensive case study from which emerged the concept of prejudice of mark, a pattern of racial discrimination prevalent in Brazil in the mid-19oos. It is an insidious and subtle form of racism that does not exclude but discriminates against the negro; it does not classify people by their ancestry (origin) but rather by their skin color and physical aspects of their appearance (phenotype). This type of racial prejudice is not absolute and definitive but rather is tuned into the spectrum of colors and tones of skin, in which basically the darker the skin color, the greater the discrimination. Social ties or personal merit can cause a shift in the classification of an individual, yet

6 For a closer look at Nogueira's participation in the UNESCO research, see Cavalcanti (1998). To see more about the range of studies in the UNESCO project, see Maio (1999). 
in the broader social environment racism remains intact. Racism in the United States, as Nogueira already explained at the end of his "Report" (Nogueira 1998), operates very differently from racism in Brazil, as it explicitly segregates and discriminates, even legally (it is notable that racial segregation was not legally abolished in the United States until as recently as 1964). Furthermore, unlike Brazil, U.S. racism classifies individuals according to their ancestry, independent of skin color. It can assume passionate characteristics, compromising the judgment of whites about acts attributed to blacks, and producing, for the group discriminated against, an ever-present and obsessive awareness of discrimination.

For editorial reasons, then, the "Report" was left out of Tanto preto quanto branco (Nogueira 1985).7 In the context of that collection from 1985, however, the gap was filled by a rich 66-page introduction (completed in 1979). In that introduction, from an emotional as well as intellectual and academic perspective, Nogueira gives a heartfelt account of the central place race relations has held in his personal and professional journey. Given the relative decline of Nogueira's work (especially in the 1960s), his "Introduction" gives the reader, like me in the early 1990s, the sense of an author's reckoning with himself and his times.

Tanto preto quanto branco posthumously honors two important individuals in Nogueira's childhood in the city of Cunha in São Paulo state. Dr. Casemiro da Rocha and Maria Rita da Silva reinforced the experience of respectful even affectionate coexistence between blacks and whites in both the public and private spheres of the small town. Dr. Casemiro de Rocha was a Bahian doctor, preto retinto ["dark black"] and the political head of Cunha during the entire First Republic (from 1899 to 1930) respected by the local white elite (who if they could, would deny his color) (Nogueira 1992). Maria Rita da Silva (the parda ["light mulato"] woman hugging two white girls in the photo on the book cover) was the beloved nanny of Oracy and his two sisters - children of public elementary school teachers. The parents' series of moves to ever-larger cities (first Catanduva, then Botucatu, and finally São Paulo) meant that

7 Years later, in 1998, the "Report" was published by Editora de Universidade de São Paulo (Edusp) under the title Preconceito de Marca: As relações raciais em Itapetininga [Prejudice of mark: Racial relations in Itapetininga] (with revision, organization and an introduction by Cavalcanti, Maria Laura). 
the "social distance [was also increasing] between the white circle to which my family belonged and the circles of people of color, such that I never again would have the opportunity to live with such intimacy that was characteristic of my childhood in my hometown," he recounted (Nogueira 1985: 56).

Race relations is also a central theme in his Master's studies, undertaken from 1942 to 1945 in the then Escola Livre de Sociologia e Politica de São Paulo ["Free School of Sociology and Politics of São Paulo"] (now the Fundação Escola de Sociologia e Política) ["School of Sociology and Politics Foundation"], and in the course of his doctorate in the Sociology Department of the University of Chicago (1945-1947). In the Escola Livre in 1939, before he graduated, Nogueira was a teaching assistant to Donald Pierson, who also became Nogueira's advisor for his Masters. ${ }^{8}$ Pierson, for his part, had been mentored by Robert Park at the University of Chicago (Valladares 2010) and his doctorate thesis was published in English ("Whites and Blacks in Bahia") in 1942, and later in Portuguese as the classic Brancos e Pretos na Bahia (Pierson 1971). Pierson brought the University of Chicago's rich tradition of sociology and anthropology to the Brazilian academic environment (Vila Nova 1998, Velho 1999, Valladares 2005), in which the study of race relations was a matter of privilege. "Race and culture," a course originally taught by Robert Park in his teaching period at the University of Chicago, was offered annually by Donald Pierson at the Escola Livre. Academic records show that Florestan Fernandes, Sérgio Buarque de Holanda and Oracy Nogueira himself took the course and the comprehensive English version of the set of lectures can be found in the Fundo Oracy Nogueira.

In the Introduction, Nogueira wrote: "As an undergraduate I came into contact with classic works by Nina Rodrigues, Manoel R. Querino, Oliveira Vianna, Arthur Ramos and Gilberto Freyre. Before going to the United States, I had already studied the works of Robert E. Park, Melville J. Herskovits, E. Franklin Frazier, W. Lloyd Warner, E.B. Reuter, Edwin R.

8 Nogueira's Master's thesis, presented in 1945, is also a classical and original work on the stigma of illness that approaches tuberculosis as a social experience. Vozes de Campos de Jordão: Experiências sociais e psíquicas do tuberculoso pulmonar no estado de São Paulo ["Voices from Campos de Jordão: Social and psychic experiences of the tuberculosis patient in São Paulo"] was republished in 2009, by Editora Fiocruz, with the organization and introduction by Maria Laura Cavalcanti. 
W. Embree, E. V. Stonequist, John Dollard, and others" (Nogueira 1985: 63). ${ }^{9}$ Nogueira arrived in the United States in 1945, shortly after the publication of two books essential for the study of relations between blacks and whites and problems of democracy in the United States: An American Dilemma by Gunnar Myrdal (1944) and Black Metropolis by St. Clair Drake and Horace R. Cayton (1945). He participated in the seminar by Drake and Cayton to promote their book and also read James Weldon Johnsons's The autobiography of an ex-coloured man, which made a profound impression on him (Nogueira 1985: 64). ${ }^{10}$ His professors included Lloyd Warner, Herbert Blumer, Louis Wirth, Robert Redfield, and Everett Hughes (his advisor). Nogueira also conducted some field research in Chicago, sharing experiences with blacks and other groups that were victims of discrimination, participating in inter-racial groups to combat racism, and undertaking a trip to the South of the country with colleagues. ${ }^{11}$

After returning to Brazil (in 1947), in the early 1950 s Nogueira was invited by Alfred Métraux to participate in the UNESCO research on racial relations, joining a group of social scientists whose names marked the era and history of Brazilian social sciences: Roger Bastide and Florestan Fernandes, Luiz de Aguiar Costa Pinto, Charles Wagley, Thales de Azevedo, and René Ribeiro, among others. As described by Maio (1999), those studies not only proposed different interpretations of racism in Brazil but also presented different ways of conceiving and applying social sciences. In this context, it can be said that Nogueira was the first intellectual clearly to grasp the anthropological and cultural nature of racial prejudice, summarized in the concepts of prejudice of mark (Brazil) / prejudice of origin (United States). Since these two types of racism arose in two very different cultures and societies, they produce significantly different effects, always unarguably negative. Through the

\footnotetext{
9 In terms of interest in social sciences in the years 1940-1960, Castro Faria (1984) noted the budding "anthropologization of sociology" or "sociologization of anthropology" practiced by Nogueira and promoted in the academic setting of the Escola Livre de Sociologia e Politica. See also the work of Corrêa (1987) for the resurgence of interest in the history of anthropology in the country. Many other studies followed, built on this foundation. 10 James Weldon Johnson also helped organize the National Association for the Advancement for the Colored People (NAACP), which Oracy Nogueira joined when he lived in the United States.

11 The Fundo Oracy Nogueira houses important documents from this rich period of the author's life, including programs of the subjects studied, drafts and final papers, field notes and, original notes on records of impressions, sketches of research projects, newspaper clippings, among other documents.
} 
identification of the dynamics of the distinct forms of racism in Brazil and in the United States, Nogueira also hoped to help the development of appropriate strategies to combat each type of discrimination.

All this took place between 1940 and 1960, which was then followed by a distinctly arid period in Nogueira's professional trajectory (Cavalcanti 1996; 2009). After Donald Pierson left the Escola Livre in 1952, the graduate studies division began a long steady decline. ${ }^{12}$ The rich theoretical dimensions of the University of Chicago's socio-anthropological tradition (Smith 1988; Coulon 1995), brought to Brazil by Donald Pierson, which were decisive in the formation of the first generations of ELSP graduates, then lost their institutional niche. Nogueira himself would leave in 1957, initiating a long itinerary through different institutions, including the Centro de Pesquisas Educacionais ["Center for Educational Studies"] in Rio de Janeiro. In this new era, São Paulo's social sciences would continue their institutionalization especially in the University of São Paulo, where in the 196os and 1970s the so-called Escola Sociológica Paulista ["Paulista School of Sociology"] would consolidate its hegemony (Miceli 1989, 1995). Nogueira would join the Faculty of Economic and Administrative Sciences at the University of São Paulo in 1968. In 1970, his expertise in "methods and techniques" paved the way for his transfer to the Department of Social Sciences (Nogueira 1964). In 1978, Nogueira became full professor of Applied Sociology in Economics in the Faculty of Economic Sciences, and retired in 1983.

As previously mentioned, in 1979 Nogueira completed his "Introduction" to the awaited collection of his previous writings on race relations which was finally published in 1985 (Nogueira 1985). And, as we indicated, only two of these works were published in the book. The study of "Pretos and Mulatos among the Middle Classes," conducted from 1983 to 1984 and finished in 1985 , was therefore undertaken in the interval between the preparation of Tanto preto quanto branco, already completed in 1979, and its publication in 1985. "Pretos and Mulatos among the Middle Classes", therefore, holds a place in the already-retired professor Nogueira's revisiting of the subject of race relations.

12 For a good overview of the incubator role of the Escola Livre from 1930-1950, see Kantor, Maciel \& Simões (2009), which combines personal testimonials and analysis. 
When we read "Pretos and Mulatos among the Middle Classes" from today's perspective of Nogueira's contribution to the understanding of Brazil's racism, ${ }^{13}$ the writing surprises us not only because of its originality and clear style but also for the author's modesty. Nogueira presents it simply as an "individual testimony eminently descriptive in style." Still he reminds us that his upbringing and lifestyle made him feel confident that his data reflected the collective and inter-subjective experience of Brazil's middle classes in general and the middle classes in São Paulo state in particular (p. 13). ${ }^{14}$

Nogueira began his research in the same year of his retirement (1983) and his writing can also be seen as a rite of passage, since he moves from a series of USP academic events to more personal social circles. Along with Velho (1978), Nogueira observes a personal universe and its particular features and transforms it into socio-anthropological knowledge.

As previously mentioned, in the USP at that time there was "no type of explicit or direct criteria for selection based on racial traits" ( $p$. 10). Seeing limited opportunities for more systematic research at the University at that moment, Nogueira decided to reexamine the subject of race relations based on his own formulation of prejudice of mark by testing the hypothesis of one of its insidious aspects: darker skin tones mean greater discrimination. "The main underlying hypothesis was that pretos would be absent from the majority of situations and events to be described, while mulatos (even if under-represented in relation to their proportion in the general population), would be present" (p.2). According Nogueira: "Racial data in Brazil must be presented disaggregated by preto, pardo and mulato, since aggregation under the single label of negro can hide the more precarious condition of the first (pretos) in relation to whites and of their greater inferiority, however slight, as compared with pardos or mulatos." (p. 13).

13 In the 1980s, DaMatta (1987) drew attention to Nogueira's formulations in his study of the "Fábula das três raças" ["Fable of Three Races"] or "Brazilian racism." Maggie (1991) also addressed Brazilian racism as a color classification system; and Farias (2006) discussed the dynamics racial relations through the analysis of color classification on Rio de Janeiro beaches. In particular, Teixeira (2003) - who discusses several of Nogueira's writings, but obviously did not know about this previously unpublished research - studied the "color" of students and professors in different academic fields at the Universidade Federal Fluminense ["Federal Fluminense University"] in the 199os in terms of analysis of statistical data and career and life paths.

14 The page numbers are those of the text original 104 typed pages that can be found at the Fundo Oracy Nogueira, now kept by Casa de Oswaldo Cruz/Fundação Oswaldo Cruz [[http:/|arch.coc.fiocruz.br]. 
Also in the early 1980 , in addition to the population census, important works on the subject of race relations were published, which the author discusses in his writing. These include the thesis of Manuela Carneiro da Cunha on black Brazilians who returned to Africa in the $19^{\text {th }}$ Century $(1985)^{15}$ (which led our author to undertake a fascinating historical incursion into colonial and imperial Brazil), an article by Hasenbalg (1983) and a book by Clóvis Moura (1983). These authors also analyzed and commented on the 1980 census data and their voices are added to Nogueira's argument. These discussions introduce an apparently unpretentious ethnographic study, conducted with a combination of tenacity and a certain refined touch of self-irony. By the end of his study, it is with confessed relief that Nogueira revealed he was finally freed of the obsession of closely examining the phenotype of all those around him. Constant and focused attention in social situations on the precise tone of skin color of those present is not a common cultural practice in Brazilian society, Nogueira tell us, and actually is quite opposite to the country's popular etiquette on race relations, which calls for discretion and not scrutiny.

Nogueira drew on his presence at, and participation in countless different academic events in the USP - including selection panels for masters and doctorates; public exams for applicants to professorship posts, varying homages, concession of honorary degrees; lectures and events - to calculate and analyze the composition of those present by color categories in the population. Likewise, with the same objective, the author also wrote of social gatherings in his personal life - baptisms, weddings, anniversaries, visits and outings, visits to a barber's shop and to a rally for democratic elections (Diretas Já).

We journey along with him, from the academic setting of the University of São Paulo to social engagements of a more personal nature in Taubaté, Osasco and Cunha (his homeland). His writing becomes steadily more expressive and fluent, narration replacing the monotony of description. This is particularly clear in the case of a visit to express condolences to the widow of an acquaintance, who although distant was greatly admired by Nogueira. The man who had died was white and from a traditional family; his widow,

15 The thesis was presented by Carneiro da Cunha at the USP in 1984 and published as a book the following year, which is why we cite the book here. 
born in Europe, also wealthy, he supposed "had African ancestry albeit remote" (p. 57). During the visit that he narrates, he had a lively conversation with a young adult mulato, educated in law, extremely intelligent, even erudite. When Nogueira was leaving, he asked the widow who the impressive young man was and was surprised by her answer: "My son!" (p. 58).

Nogueira worked from an ethnographic perspective, identifying natural categories based on common sense to describe people from their own perspective. This strategy enabled him to demonstrate again and again his theory that Brazilians perceive people based on their physical features or characteristics and not on their origin. As in a friendly conversation, the situations and stories Nogueira writes about present convincing data and persuasively reveal the subtle dynamic of prejudice of mark in action in the context of São Paulo's middle classes.

To translate Nogueira's exquisite analysis into English, then, is not an easy task. The first footnote of this text addresses the difficulty of translating racial classification terms, which tend to be charged with particular cultural and symbolic meanings, which themselves vary from situation to situation. In his writing, Oracy Nogueira uses racial categories with great propriety, following the current use in the literature at that time or by those interviewed. The problem calls for the reader's careful attention. The term most widely used by Nogueira in his text is preto, which sometimes comes from day to day usage, sometimes from demographic censuses. Censuses from more than 100 years ago used the population's self-classification for color, requesting interviewees to select between categories of color/race: branco, pardo, preto, amarelo and (after 1988) indigena. However, the term negro, which translates into English as black, is also used by the author in some passages with the meaning made popular by the black movements, that is, as a racial identity, although rarely used in day to day life in the early 1980 s. The 1980 , however, as already noted, were transitional years. During that period, sociologists also began sometimes using the term negro to refer to those who declared themselves either preto or pardo in census returns. Although Nogueira did not fully agree with this strategy (which in his view camouflaged the real situation of pretos in Brazilian society), he did use it in some instances.

In the introductory passage on the history of slavery in Brazil, Nogueira outlines the continuities and ruptures that occurred with abolition. His 
careful attention to the terminology of social classifications allows him to show that, even in slavery, distinctions de marca [of mark] already existed, as well as an ambiguity in meaning of the terms livre [free], liberto [freed] and escravo [slave]. Slaves are described with the historiographical expressions that use "africano" to designate an African-born slave or liberto, and "crioulo" for a slave or liberto born in Brazil. For Nogueira's argument, it is significant that the latter, born here, could be preto or pardo. Culturally, the term crioulo in Brazil, therefore, has a very different meaning than its current English translation "Creole" (a descendent of Europeans born in the colonies or mestizo of black and European descent). Also, in the literature and documents from the period of slavery to the mid-2oth century (especially newspapers), the term preto was commonly used to refer to slaves; later, the term negro became popular in referring to a slave who rebelled or escaped (Schwarcz 1987).

In Nogueira's descriptions of individual physical characteristics observed in events in São Paulo in 1983 and 1984, he alternated between "negroid characteristics" and "mark of African ancestry." In the accounting and analysis of color categories used in these events, the classification spectrum opens wide, ranging from preto retinto [dark black] to darker or lighter mulatos - pardos, pardos claros, morenos, morenos claros and finally the neighboring types that include "a limit of tolerance that may vary from region to region, according to the population density of negros and mestiços" (p. 24). The term mulata, which has a special connotation in Brazil, is sometimes used to refer to women. The double meaning of the term moreno is noteworthy, referring to both dark color from birth as well as the darkening of skin color resulting from exposure to the sun. Moreno is still the most widely used category in Brazil's race relations etiquette to refer to dark-skinned people without directly referring to color or "race".

Finally, we draw attention to Nogueira's choice to use pretos and mulatos in the title of his study. The decision is consistent with his hypothesis that, while every shade in Brazil's racial color spectrum suffers the effects of prejudice of mark, pretos are the group that feels the effects most strongly. To understand Brazil's racial situation, Norgueira believes that data must be disaggregated in categories of preto, pardo and mulato and not aggregated in the single category of negro. 
The problem of Brazilian racism, Nogueira tell us, results from the association of dark color with servile conditions and low social status, a cruel legacy left by the past of slavery. Outside the time limits of a real but historically circumscribed symbolic association, Brazilian society had evolved this particular association, transforming and assigning black population's phenotype features to reified symbols of social status. With the steady growth of mixed marriages, especially among the poor, and a certain flexibility in social mobility of some black populations (although extremely limited, for example, in comparison with the absorption of the Italians in São Paulo as shown by Nogueira in his study in Itapetininga), this symbolic reification of phenotype features would also explain, according to our author, the "embarrassment of color" in more favorable social settings. Such details of classification and variability produced a "poly-segmentation" in Brazil that goes along with discrimination by shunning, a kind of ritualized avoidance. Nogueira insists, however, that the population is never divided into two distinct groups - a problem that the United States has faced and continues to face (occasionally dramatically) in the present.

With respect to the University of Sao Paulo, Nogueira reflects that it is an academic institution of excellence and therefore would naturally be highly selective. However, the general presence of mulatos in the events studied and the infrequent presence of pretos clearly revealed the under-representation of pretos in the academic environment, based on the 1980 census's population composition by color category. For Nogueira, discrimination alone does not explain the full picture. In his view, determinants included structural socioeconomic factors, the universe of cultural expectations, and unequal access to basic primary and secondary schools.

The prophetic nature of Nogueira's essay is worthy of note. It comes down to us as a lesson for the future, to which he might well return, as we now do with the eyes of the present.

Translated by Lyle Prescott

\section{References}

FERNANDES, Florestan; BASTIDE, Roger (orgs). 1955. Relações raciais entre negros e brancos em São Paulo. São Paulo: Ed. Anhembi. 
CASTRO FARIA, Luis de. 1984. "Depoimentos sem compromissos de um militante em recesso". Anuário Antropológico de 1982. Rio de Janeiro/ Fortaleza: Tempo Brasileiro, Universidade Federal de Fortaleza. pp. 228-250. CORRÊA, Mariza. 1987. História da antropologia no Brasil. Depoimentos (19301960). São Paulo/ Campinas: Ed. Vértice.

COULON, Alain. 1995. A Escola de Chicago. São Paulo: Papirus Ed.

DaMATTA, Roberto. 1981. "Digressão; a fábula das três raças, ou o problema do racismo à brasileira”. In: Relativizando. Uma introdução à antropologia social. Rio de Janeiro: Ed. Rocco. pp. 58-85.

CAVALCANTI, Maria Laura Viveiros de Castro. 2009. "Estigma e relações raciais na obra pioneira de Oracy Nogueira”. In: A. Botelho; L. Schwarcz (orgs.), Um enigma chamado Brasil. São Paulo: Companhia das Letras. pp. 256-267.

. 1998. "Apresentação". In: O. Nogueira. Preconceito de marca. As relações raciais em Itapetininga. São Paulo: Edusp. pp. 9-19.

. 1996. "Oracy Nogueira e a antropologia no Brasil: o estudo do estigma e do preconceito racial”. Revista Brasileira de Ciências Sociais, 31(11): 5-28.

CARNEIRO DA CUNHA, Maria Manuela. 1985. Negros estrangeiros. Os escravos libertos e sua volta à África. São Paulo: Editora Brasiliense.

DRAKE, St. Clair \& CAYTON, Horace. 1945. Black metropolis. 2 vols. New York: Harper \& Row.

FARIAS, Patrícia. 2006. Pegando uma cor na praia: relações raciais e classificação de cor na cidade do Rio de Janeiro. Rio de Janeiro: Prefeitura Municipal.

FRY, Peter. 2005. A persistência da raça. Ensaios antropológicos sobre o Brasil e a África Austral. Rio de Janeiro: Civilização Brasileira. .; MAGGIE, Yvonne; CHOR MAIO, Marcos; MONTEIRO, Simone; SANTOS, Ricardo Ventura (orgs.) 2007. Divisões perigosas. Políticas raciais no Brasil Contemporâneo. Rio de Janeiro: Civilização Brasileira.

HASENBALG, Carlos. 1983 “Anotações sobre a classe média no Rio de Janeiro. Revista de Antropologia, 26: 53-61.

KANTOR, Iris; MACIEL, Débora \& SIMÕES, Júlio (orgs.). 2009. A Escola Livre de Sociologia e Política. Anos de Formação. 1933-1953. Depoimentos. São Paulo: Editora Sociologia e Política. $2^{a}$ ed. revista e ampliada.

MAIO, Marcos Chor. 1999. "O projeto Unesco e a agenda das ciências sociais no Brasil dos anos 40 e 50". Revista Brasileira de Ciências Sociais, 14(41): 141-158. 
.; SANTOS, Ricardo Ventura. 2005. "Política de cotas raciais, os

"olhos da sociedade" e os usos da antropologia: o caso do vestibular na

Universidade de Brasília”. Horizontes Antropológicos, 11(23): 181-214.

MAGGIE, Yvonne. 1991. “A ilusão do concreto: análise do sistema de

classificação racial no Brasil.” Tese apresentada para concurso de Profa.

Titular. IFCS/UFRJ. Mimeo.

MICELI, Sérgio. 1989. História das ciências sociais no Brasil. Vol. 1. São Paulo:

Vértice.

. 1995. História das ciências sociais no Brasil. Vol. 2. São Paulo: Vértice.

MOURA, Clóvis. 1983. Brasil: raízes do protesto Negro. São Paulo: Ed. Global.

MYRDAL, Gunnar. 1962 [1944]. An American dilemma: the negro problem and

modern democracy. New York: Harper \& Row.

NOGUEIRA, Oracy. 2009. Vozes de Campos de Jordão. Experiências sociais e

psíquicas do tuberculoso pulmonar no estado de São Paulo. Rio de Janeiro: Ed.

Fiocruz. Organização e Introdução de Maria Laura Cavalcanti.

.1998. Preconceito de marca: as relações raciais em Itapetininga. São Paulo:

Edusp. Organização e Introdução de Maria Laura Cavalcanti.

. 1992. Negro político, político negro. São Paulo: Edusp.

1985. Tanto preto quanto branco. São Paulo: T. A. Queiroz.

. 1964. Pesquisa social: introdução a suas técnicas. São Paulo: Companhia

Editora Nacional.

PIERSON, Donald. 1971 [1942]. Bancos e pretos na Bahia. São Paulo: Companhia

Editora Nacional. Coleção Brasiliana, volume 241.

SCHWARCZ, Lilia. 1987. Retrato em branco e negro: jornais, escravos e cidadãos em São Paulo no final do século XIX. São Paulo: Cia. das Letras.

SMITH, Dennis. 1988. The Chicago School. A liberal critique of capitalism. New York: St. Martin's Press.

TEIXEIRA, Moema Poli. 2003. Negros na universidade. Identidade e trajetórias de ascensão social no Rio de Janeiro. Rio de Janeiro: Pallas Editora.

VALLADARES, Lícia do Prado. 2010. "A visita de Robert Park ao Brasil, o 'Homem Marginal'e a Bahia como laboratório". Caderno CRH, Salvador, Centro de Recursos Humanos da Universidade Federal da Bahia, 23(58): 35-49. . (o.) . 2005. A Escola de Chicago; impacto de uma tradição no Brasil e na França. Belo Horizonte: Universidade Federal de Minas Gerais. 
VELHO, Gilberto. 1999. "Apresentação. Anselm Strauss: indivíduo e vida social”. In: Anselm Strauss. Espelhos e máscaras. São Paulo: Edusp. pp. 11-19.

. 1978 “Observando o familiar". In: Edson Nunes (org.), Aventura sociológica. Objetividade, paixão, improviso e método na pesquisa social. Rio de Janeiro: Zahar. pp. 36-46.

VILA NOVA, Sebastião. 1998. Donald Pierson e a Escola de Chicago na sociologia brasileira: entre humanistas e messiânicos. Lisboa: Vega.

Maria Laura Viveiros de Castro Cavalcanti

Federal University of Rio de Janeiro

cavalcanti.laura@gmail.com 